\title{
Effect of Organic and Inorganic Sources of Nutrients on Shelf Life and Yield Attributes of Guava Cv. Allahabad Safeda
}

\author{
Ramavath Priyanka $^{1 *}$, A. Gopala Krishna Reddy ${ }^{2}$, Veena Joshi ${ }^{3}$ and M. Sreedhar ${ }^{4}$ \\ ${ }^{1}$ Department of Fruit Science, College of Horticulture, SKLTSHU, Rajendranagar, \\ Hyderabad, Telangana, India \\ ${ }^{2}$ Central Research Institute for Dryland Agriculture, Santoshnagar, Hyderabad, India \\ ${ }^{3}$ College of Horticulture, SKLTSHU, Mojerla, Wanaparthy, Telangana, India \\ ${ }^{4}$ Regional Sugarcane and Rice Research Station, Rudrur, Nizamabad, Telangana, India \\ *Corresponding author
}

\section{A B S T R A C T}

\section{Keywords}

Guava,

Organic and

Inorganic Fertilizer,

Fruit yield,

Shelf life

Article Info

Accepted:

12 May 2021

Available Online:

10 June 2021
The present investigation entitled "Effect of Organic and Inorganic sources of nutrients on shelf life and yield attributes of Guava (Psidium guajava L.) Cv. Allahabad Safeda" was carried out during the year 2018-2019 at Gunegal Research Farm, CRIDA, Santoshnagar. The experiment was laid out in Randomized Block Design (RBD) with five treatments and four replications. With respect to yield parameters, $\mathrm{T}_{4}$ - Inorganic $(75 \%)(\mathrm{NPK})+$ Organic $(25 \%)(\mathrm{FYM})$ recorded maximum fruit weight $(185.70 \mathrm{~g})$, number of fruits per tree (215), fruit yield $\left(39.93 \mathrm{~kg} /\right.$ tree) followed by $\mathrm{T}_{5}$-Organic $(50 \%)(\mathrm{FYM})+$ Inorganic $(50 \%)(\mathrm{NPK})$ and minimum was recorded in $\mathrm{T}_{1^{-}}$Organicsole $(100 \%)(\mathrm{FYM})$. The treatment $\left(\mathrm{T}_{5}\right)$ comprising Organic $(50 \%)(\mathrm{FYM})+$ Inorganic $(50 \%)(\mathrm{NPK})$ recorded significantly highest fruit firmness $\left(8.96 \mathrm{~kg} / \mathrm{cm}^{2}\right)$, shelf life (10.11 days) and minimum physiological loss in weight $(19.07 \%)$ at $10^{\text {th }}$ day of storage.

\section{Introduction}

Guava (Psidium guajava L.) is one of the most important fruit crops of Myrtaceae family grown widely in tropical and subtropical regions of India. Guava is a native of Tropical America, Mexico and Peru. In India guava was introduced by Portuguese in early 17 th century.

Guava ranks as fourth most important crop in India after Mango, Banana and Citrus covering an area of about 2,64,900 ha with production of around 40,53,500 MT and productivity about $15.3 \mathrm{MT} / \mathrm{ha}$ (NHB, 2018). The most important guava growing states are Bihar, Uttar Pradesh, Madhya Pradesh, Punjab, Maharashtra, Andhra Pradesh and Telangana. Uttar Pradesh is by far the most important guava producing state of India, and Allahabad has the reputation of growing the best guava in the country as well as in the world. 
Guava is one of the cheapest and popular fruit of India. It can be grown satisfactorily on marginal soils with minimum care and is also called 'Apple of the Tropics'. Guava is only a delicious and nutritious table fruit but may also be utilized to make products like jam, jelly preparation. Leaves are used for curing diarrhea and also for dying and tanning.

In northern India, guava produces flowers twice in a year, Ambe Bahar and Mrig Bahar (Gupta and Nijjar, 1978) whereas in southern states viz., Maharashtra, Tamil Nadu Andhra Pradesh and Telangana, there is a third crop which flowers in winter and become mature fruits in spring are called HasthBahar (Hayes, 1970).

Cultivation of guava is getting popular due to increasing international trade, better nutritional contents and processing of its value added products. This is a well known fact that increase in productivity of tree removes large amount of essential nutrients from the soil. Without proper management, continuous fruit production reduces nutrient reserves in the soil. Another issue of great concern is the sustainability of soil productivity, as land began to be intensively exhausted causing depletion of soil fertility thereby ending up to soil degradation.

Guava is a rich and chief source of vitamin C, pectin and contains fair amounts of calcium, phosphorus and vitamin A (Phadnis, 1970). Whole fruit is eaten fresh. Thus there is possibility of entry of residues of agrochemicals into human body causing detrimental effects on human health, which can be avoided to a large extent by cultivating guava organically. The importance of guava is also due to the fact that it is a hardy fruit that can be grown in wasteland or poorly drained soils without any manuring or irrigation and adoption of organic farming produces chemical free healthy food and improves soil physical and chemical properties thereby maintaining the soil health.

Continuous use of inorganic fertilizers as source of nutrient in imbalanced proportion is also a problem, causing inefficiency, damage to the environment \& in certain situations, harms the plant themselves and also to human being who consume them (Shanker et al.,2002).

Integrated nutrient management is the most appropriate approach for managing the nutrient input. In integrated plant nutrition supply system, the basic goal is to maintain or possibly improve the soil fertility and plant nutrient supply to an optimum level for sustaining the desired crop productivity through optimization of the benefits from all possible sources of plant nutrients in an integrated manner. Guava is very hardy to soil and agro-climatic conditions and give good response to manuring in terms of increasing fruit production and quality. Fertilizer experiments conducted in India showed that guava has given good response to balanced use of inorganic fertilizers along with organic manures. It is reported that application of organic and chemical fertilizers not only increased the yield, but also improved the fruit quality in guava (Naik and Babu, 2007).

In recent years, the market for organic farming has significantly increased in response to concern over food quality and environmental matters. Organic food is quite attractive for consumers and is often associated with quality, healthy, and natural products in opposition to the more processed and artificial conventional food.

\section{Materials and Methods}

The field experiment was carried out during the year 2018-2019 at Gunegal Research Farm, ICAR-CRIDA, Santoshnagar. It is 
situated at $78.66^{\circ} \mathrm{E}$ longitude and $17.08^{\circ} \mathrm{N}$ latitude and at 626 meter above sea level (MASL). The soil of the orchard selected is a medium sandy clay loam with a $\mathrm{pH}$ of 6.78 and electrical conductivity of $0.09 \mathrm{dSm}^{-1}$.

The availability of nitrogen, phosphorus and potassium per hectare is 210.20, 16 and 188 kilograms respectively. The experiment was laid out in Randomized Block Design (RBD) with four replications and five treatments namely $\mathrm{T}_{1}$ - Organic sole $(100 \%)$ (in the form of FYM), $\mathrm{T}_{2}$ - Inorganic sole $(100 \%)$ $(\mathrm{N}: \mathrm{P}: \mathrm{K}), \quad \mathrm{T}_{3}-$ Organic $(75 \%)(\mathrm{FYM})+$ Inorganic $(25 \%)(\mathrm{N}: \mathrm{P}: \mathrm{K}), \mathrm{T}_{4}-$ Inorganic $(75 \%)(\mathrm{N}: \mathrm{P}: \mathrm{K})+$ Organic $(25 \%)(\mathrm{FYM}), \mathrm{T}_{5}-$ Organic $(50 \%)(\mathrm{FYM})+$ Inorganic $(50 \%)(\mathrm{N}: \mathrm{P}: \mathrm{K})$. Organic source of nutrient used is FYM and Inorganic sources of nutrient used are Urea, DAP and MOP. Half dose of urea and full dose of diammonium phosphate and muriate of potash were applied on first week of July and remaining half dose of nitrogen was applied in two equal splits one month after first dose.

The whole of the organic manure (farm yard manure) was incorporated along the basin. Observations recorded such as fruit weight (g) was measured with electronic balance, firmness $\left(\mathrm{kg} / \mathrm{cm}^{2}\right)$ was calculated with penetrometer. The shelf life of fruits was determined by recording the number of days the fruits remained in good condition during storage without spoilage and other parameters like Physiological loss in weight $(\%)$, number of fruits per tree and Fruit yield ( $\mathrm{kg} /$ tree) were recorded after harvest.

\section{Results and Discussion}

The results obtained on effect of organic and inorganic sources of nutrients on shelf life and yield attributes of guava $\mathrm{Cv}$. Allahabad Safeda are presented below.

\section{Fruit weight (g)}

Maximum fruit weight $(185.70 \mathrm{~g})$ was observed with the treatment $\left(\mathrm{T}_{4}\right)$ comprising Inorganic (75\% NPK) + Organic (25\% FYM) followed by $\mathrm{T}_{5^{-}}$Organic $(50 \%$ FYM $)+$ Inorganic $(50 \% \quad \mathrm{NPK}) \quad(173.38 \mathrm{~g})$ and significantly minimum fruit weight $(112.91 \mathrm{~g})$ was recorded in $\mathrm{T}_{1}$-Organic sole $(100 \%$ FYM) (Table 1). The increase in average fruit weight was due to the combined application of inorganic and organic fertilizers in $T_{4}$ improved soil nutrient availability and triggered various biological processes at soil rhizosphere, which provided better nourishment to the plant resulting in higher fruit weight. The results are in close conformity with the finding of Athaniet al., (2007) in guava.

\section{Number of fruits per tree}

All treatments differed significantly with respect to number of fruits per tree.Highest number of fruits per tree was recorded in $\mathrm{T}_{4}$ Inorganic (75\% NPK) + Organic (25\% FYM) (215.00) followed by $\mathrm{T}_{5^{-}}$Organic (50\% FYM) + Inorganic (50\% NPK) (206.00) and significantly minimum number of fruits per tree $(160.50)$ was recorded in $\mathrm{T}_{1}$-Organic sole (100\% FYM).

\section{Fruit yield (kg/tree)}

Highest fruit yield (39.93 $\mathrm{kg} /$ tree $)$ was recorded in $\mathrm{T}_{4}$ - Inorganic $(75 \% \mathrm{NPK})+$ Organic (25\% FYM) followed by $\mathrm{T}_{5}$ - Organic (50\% FYM) + Inorganic (50\% NPK) (36.02 $\mathrm{kg} /$ tree) and significantly lowest yield (18.12 $\mathrm{kg} /$ tree) was recorded in $\mathrm{T}_{1}$-Organic sole (100\% FYM).

Addition of FYM along with NPK fertilizers might have helped in improving soil physicochemical and biological properties which ultimately improved plant growth and yield in 
terms of number of fruits, fruit weight and yield. The above results are in accordance with the findings of Singh and Banik (2011) in mango, Athaniet al., (2007) in guava, Shukla et al., (2009) and Gupta et al., (2019).

Table.1 Effect of organic and inorganic sources of nutrients on physical parameters of guava (Psidium guajava L.) Cv. Allahabad Safeda

\begin{tabular}{|l|c|c|c|c|c|}
\hline Treatments & $\begin{array}{c}\text { Fruit weight } \\
(\mathbf{g})\end{array}$ & $\begin{array}{c}\text { Number of } \\
\text { fruits per tree }\end{array}$ & $\begin{array}{c}\text { Fruit yield } \\
(\mathbf{k g} / \text { tree })\end{array}$ & $\begin{array}{c}\text { Fruit Firmness } \\
\left(\mathbf{k g} / \mathbf{c m}^{\mathbf{2}}\right)\end{array}$ & $\begin{array}{c}\text { Shelf life } \\
(\text { days) }\end{array}$ \\
\hline $\mathrm{T}_{1}$ & $112.91^{\mathrm{e}}$ & $160.50^{\mathrm{e}}$ & $18.12^{\mathrm{e}}$ & $7.87^{\mathrm{d}}$ & $7.91^{\mathrm{d}}$ \\
\hline $\mathrm{T}_{2}$ & $163.60^{\mathrm{c}}$ & $191.25^{\mathrm{c}}$ & $31.21^{\mathrm{c}}$ & $7.45^{\mathrm{e}}$ & $8.22^{\mathrm{c}}$ \\
\hline $\mathrm{T}_{3}$ & $151.54^{\mathrm{d}}$ & $172.75^{\mathrm{d}}$ & $26.18^{\mathrm{d}}$ & $8.18^{\mathrm{c}}$ & $7.53^{\mathrm{e}}$ \\
\hline $\mathrm{T}_{4}$ & $185.70^{\mathrm{a}}$ & $215.00^{\mathrm{a}}$ & $39.93^{\mathrm{a}}$ & $8.62^{\mathrm{b}}$ & $9.04^{\mathrm{b}}$ \\
\hline $\mathrm{T}_{5}$ & $172.38^{\mathrm{b}}$ & $206.00^{\mathrm{b}}$ & $36.02^{\mathrm{b}}$ & $8.96^{\mathrm{a}}$ & $10.11^{\mathrm{a}}$ \\
\hline $\mathrm{S} . \mathrm{Em} \pm$ & 1.79 & 1.60 & 0.51 & 0.05 & 0.04 \\
\hline CD at 5\% & 5.56 & 5.50 & 1.60 & 0.15 & 0.11 \\
\hline
\end{tabular}

Table.2 Effect of organic and inorganic sources of nutrients on physiological loss in weight (\%) of guava (Psidium guajava L.) Cv. Allahabad Safeda

\begin{tabular}{|l|c|c|c|c|c|}
\hline \multirow{2}{*}{ Treatments } & \multicolumn{5}{|c|}{ Physiological loss in weight (\%) } \\
\cline { 2 - 6 } & $\mathbf{2}^{\text {nd }} \mathbf{d a y}$ & $\mathbf{4}^{\text {th }} \mathbf{d a y}$ & $\mathbf{6}^{\text {th }}$ day & $\mathbf{8}^{\text {th }}$ day & $\mathbf{1 0}^{\text {th }}$ day \\
\hline $\mathrm{T}_{1}$ & $1.87^{\mathrm{a}}$ & $7.10^{\mathrm{a}}$ & $12.86^{\mathrm{a}}$ & $17.78^{\mathrm{a}}$ & $*$ \\
\hline $\mathrm{T}_{2}$ & $1.79^{\mathrm{b}}$ & $4.24^{\mathrm{c}}$ & $8.76^{\mathrm{c}}$ & $15.00^{\mathrm{c}}$ & $19.81^{\mathrm{b}}$ \\
\hline $\mathrm{T}_{3}$ & $1.83^{\mathrm{a}}$ & $4.36^{\mathrm{b}}$ & $8.96^{\mathrm{b}}$ & $15.29^{\mathrm{b}}$ & $*$ \\
\hline $\mathrm{T}_{4}$ & $1.72^{\mathrm{c}}$ & $4.17^{\mathrm{d}}$ & $8.55^{\mathrm{d}}$ & $14.58^{\mathrm{d}}$ & $21.71^{\mathrm{a}}$ \\
\hline $\mathrm{T}_{5}$ & $1.65^{\mathrm{d}}$ & $4.08^{\mathrm{e}}$ & $8.16^{\mathrm{e}}$ & $14.31^{\mathrm{e}}$ & $19.07^{\mathrm{c}}$ \\
\hline S.Em \pm & 0.023 & 0.027 & 0.060 & 0.044 & 0.129 \\
\hline CD at 5\% & 0.072 & 0.083 & 0.188 & 0.137 & 0.403 \\
\hline
\end{tabular}

Fig.1 Effect of organic and inorganic sources of nutrients on physiological loss in weight (\%) of guava (Psidium guajava L.) Cv. Allahabad Safeda

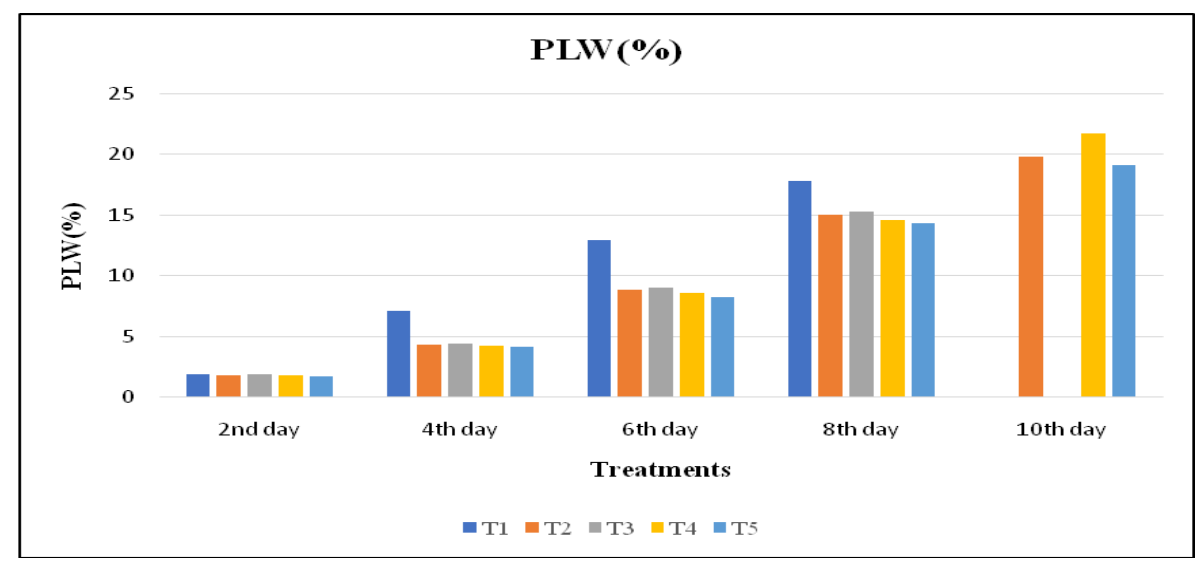




\section{Fruit firmness $\left(\mathrm{kg} / \mathrm{cm}^{2}\right)$}

There was significant difference observed among the treatments for firmness. Highest firmness (8.96) was recorded in $\mathrm{T}_{5}$-Organic $(50 \%$ FYM $)+$ Inorganic $(50 \%$ NPK) followed by $\mathrm{T}_{4-}$ Inorganic (75\% NPK) + Organic (25\% FYM) (8.62) and lowest firmness (7.45) was observed in $\mathrm{T}_{2}$-Inorganic sole (100\% NPK) (Table 1). The combination of organic and inorganic fertilizers increased the efficiency of micro and macro nutrients which are essential for cell wall structure and function of fruit by stabilizing peptic networks and regulating cell wall pore size which makes the fruit firm. The results are similar to the findings Patel et al., (2017) in sapota and Kumar et al., (2017) in guava.

\section{Shelf life (days)}

Significantly maximum shelf life (10.11) was recorded in $\mathrm{T}_{5^{-}}$Organic $(50 \%$ FYM $)+$ Inorganic $(50 \% \mathrm{NPK})$ followed by $\mathrm{T}_{4^{-}}$ Inorganic (75\% NPK) + Organic (25\% FYM) (9.04) and minimum shelf life was recorded in $\mathrm{T}_{3}$ - Organic (75\% FYM) + Inorganic (25\% NPK) (7.53) (Table 1).

Sahuet al., (2017) reported that maximum shelf life might be due to altered physiology and biochemistry of the fruit as influenced by both organic and inorganic fertilizers that reduced respiration and transpiration which intern resulted in low cumulative physiological loss in weight and increased shelf life in guava. The results are in close conformity with the findings of Lodaya and Masu (2019), Kumar et al., (2017) in guava and Patel et al., (2017) in sapota.

\section{Physiological loss in weight (\%)}

All treatments showed significant difference with respect to physiological loss in weight. The minimum weight loss after two days
(1.64 \%), four days $(4.08 \%)$, six days (8.16 $\%)$, eight days (14.31\%) and after ten days $(19.07 \%)$, respectively, was observed in $\mathrm{T}_{5^{-}}$ Organic (50\% FYM)+ Inorganic (50\% NPK) (Table 2).

The reduction in weight loss in fruit may be due to reduction in rate of respiration and transpiration, which delayed ripening process by supporting the ethylene synthesis during the fruit ripening. The above results are in accordance with the findings of Patel et al., (2017) in sapota and Kumar et al., (2017) in mango.

From the present investigation it is concluded that among the treatment combinations the treatment $\mathrm{T}_{4^{-}}$Inorganic $(75 \% \quad \mathrm{NPK})+$ Organic (25\% FYM) showed positive effect on yield attributes and maximum shelf life, firmness and minimum physiological loss in weight was recorded in $\mathrm{T}_{5}$ - Organic (50\% FYM)+ Inorganic (50\% NPK) followed by $\mathrm{T}_{4-}$ Inorganic $(75 \% \mathrm{NPK})+$ Organic $(25 \%$ FYM).

\section{References}

Athani, S.I., Prabhuraj,H.S., Ustad, A.I., Swamy, G.S.K., Patil, P.B. and Kotikal, Y.K. 2007. Effect of organic and inorganic fertilizers on growth, leaf, major nutrient and chlorophyll content and yield of Guava cv. Sardar. Acta horticulture. 735:351-356.

Gupta, M, R. and Nijjar, G. S. 1978. Crop regulation on guava. Indian Journal of Horticulture. 35:23-27.

Gupta, P., Singh, D., Prasad, V. M. and Kumar, V. 2019. Effect of integrated nutrient management on growth and yield of Guava (Psidium guajava L.) cv. Allahabad safeda under high density planting. Journal of pharmacognosy and phytochemistry. 8(1): 1233-1236.

Hayes, W. B. (1970). Fruit growing in India. 
Kitabmahal, Allahabad.

Kumar, R. K., Jaganath, S., Guruprasad, T. R. and Ulla, H. M. T. 2017. Planting geometry, Integrated nutrient management and Its effect on postharvest quality of guava cv. Lalit during rainy season. International Journal of Pure and Applied Bioscience. 5(1):720-728.

Kumar, R., Jadav, J.K., Rai, A. K., Khajuria, S. and Lata, K. 2017. Efficacy of integrated nutrient management in mango (Mangifera indica) cv. Kesar under semi-arid conditions of central Gujarat. Indian Journal of Agricultural Sciences. 87(7):947-952.

Lodaya, B. P. and Masu, M. M. 2019. Effect of biofertilizer, manures and chemical fertilizers on fruit quality and shelf life of guava (Psidium guajava L.) cv. Allahabad safeda. Internatinal Journal of Chemical Studies. 7(4):1209-1211.

Naik, M. H. and Babu, R. S. 2007. Feasibility of organic farming in guava (Psidium guajava L.). Acta Horticulturae. 735:365-372.

NHB, 2018, National Horticulture Board, Gurgaon, India.

Patel, M., Vihol, N. J., Patel, A. D. and Patel, H. C. 2017. Effect of integrated nutrient management on quality parameters of sapota cv. Kalipatti. International
Journal of Chemical Studies. 5(6):889891.

Phadnis, N. A. (1970). Improvement of guava (Psidium guajava L.) by selection in Maharastra. Indian Journal of Horticulture. 27(3/4): 99-105.

Sahu, P. K., Dikshit, S. N. and Sharma, H. G. 2017. Studies on the effect of cowdung slurry, chemical fertilizers and biofertilizers on fruit quality and shelf life of guava (Psidium guajava L.) under Chhattisgarh plains. International Journal of Chemical Studies. 5(5):16691672.

Shanker, Uma., Pathak, R. A., Pathak, R. K., Ojha, C. M. 2002. Effect of NPK on the yield and fruit quality of guava cv. Sardar. Progressive Horticulture. 34(1):49-55.

Shukla, A. K., Sarolia, D. K., Kumari, B., Kaushik, R. A., Mahawer, L. N. and Bairwa, H. L. 2009. Evaluation of substrate dynamics for integrated nutrient management under high density planting of guava cv. Sardar. Indian Journal of Horticulture. 66(4):461-464.

Singh, S. R. and Banik, B. C. 2011. Response of integrated nutrient management on flowering, fruit setting, yield and fruit quality in mango cv. Himsagar. Asian Journal of Horticulture. 6(1):151-154.

\section{How to cite this article:}

Ramavath Priyanka, A. Gopala Krishna Reddy, Veena Joshi and Sreedhar, M. 2021. Effect of Organic and Inorganic Sources of Nutrients on Shelf Life and Yield Attributes of Guava Cv. Allahabad Safeda. Int.J.Curr.Microbiol.App.Sci. 10(06): 91-96. doi: https://doi.org/10.20546/ijcmas.2021.1006.009 